Gabriele Gava*

\title{
Peirce's "Ideas, stray or stolen, about scientific writing" and the relationship between methodeutic, speculative rhetoric, and the universal art of rhetoric
}

\author{
https://doi.org/10.1515/sem-2016-0076
}

\begin{abstract}
This paper is a reading of Peirce's manuscript "Ideas, stray or stolen, about scientific writing." The latter text has been considered to be a key for understanding the relationship between speculative rhetoric and methodeutic. While I agree that it includes essential reflections on the third branch of Peirce's logic, I will argue that the classification of rhetoric studies that it contains cannot be used to clarify the way in which methodeutic and speculative rhetoric are related to one another. I will first introduce the classification as it is presented by Peirce in "Ideas, stray or stolen, about scientific writing" and list some problems that immediately arise when we identify methodeutic with the rhetoric of science. Then, I will elucidate Peirce's distinction between the universal art of rhetoric, speculative rhetoric, and ordinary rhetoric. I will argue that the classification of rhetoric studies in "Ideas, stray or stolen, about scientific writing" should be seen as a classification of the ways in which we can obtain different ordinary rhetorics specifying the contents of speculative rhetoric for different contexts of sign use. To finish, I will propose a different approach to support the claim that methodeutic is a subdivision of speculative rhetoric.
\end{abstract}

Keywords: Charles S. Peirce, rhetoric, methodeutic

\section{Introduction}

This paper is a reading of Peirce's manuscript "Ideas, stray or stolen, about scientific writing" (hereafter "Ideas"). The latter text has been considered to be a key for understanding the relationship between speculative rhetoric and methodeutic. While I agree that it includes essential reflections on the third branch of Peirce's logic, I will argue that the classification of rhetoric studies that it contains cannot be used to clarify the way in which methodeutic and speculative rhetoric are related to one another.

*Corresponding author: Gabriele Gava, Goethe-Universität, 60323 Frankfurt, Germany, E-mail: gabriele.gava@gmail.com 
Having been almost neglected for a long time, the third branch of Peirce's logic has obtained increasing attention in the last couple of decades (cf. Santaella-Braga 1999; Liszka 2000; Bergman 2000, 2009; Colapietro 2007). We could try to explain the lack of consideration that this discipline has suffered in the past in various ways. Arguably, one of the main reasons for this scarcity of studies on the subject was due to the lack of specificity of Peirce's investigations on this topic. In fact, if one compares Peirce's examinations of speculative grammar and critic with Peirce's claims on speculative rhetoric, the first, second, and third branches of Peirce's logic, respectively, one cannot fail to notice that his considerations on rhetoric often sound more like programmatic proposals than like detailed analyses of the subject. This problem is strictly related to another one, that is, to the difficulty of establishing with exactness the object of the third branch of Peirce's logic. The latter is, for example, alternatively defined as a study of "the methods that ought to be pursued in the investigation, in the exposition, and in the application of truth" (EP 2: 260, 1903), as "the doctrine of the general conditions of the reference of Symbols and other Signs to the Interpretants which they aim to determine" (CP 2.93, 1902), or as "the study of the necessary conditions of the transmission of meaning by signs from mind to mind, and from one state of mind to another" (CP 1.444, 1986c.). Just as there is diversity within Peirce's definitions of the third branch of logic, so there is an important development in Peirce's preferred name for this science. Peirce named it rhetoric (specified as either speculative, general, universal, or pure) until around 1902, when he began to call it methodeutic. In this respect, it is not clear if this was only a change in designation or if methodeutic was in fact a new discipline with objects of its own.

These are thus among the central problems that are currently discussed in the flourishing literature on Peirce's third branch of logic. In this paper I will concentrate my attention on the relationship between speculative rhetoric and methodeutic and on the related issue concerning the determination of their exact contents. In particular, I will argue that the classification of rhetoric studies that is contained in "Ideas, stray or stolen, about scientific writing" cannot be used to determine how speculative rhetoric and methodeutic relate to one another. ${ }^{1}$ In the literature on the relationship between speculative rhetoric and methodeutic, Peirce scholars have displayed basically four approaches. John Michael Krois (1981) has suggested that methodeutic and speculative rhetoric should be considered as two basically different disciplines: one studying the conditions of instrumental thinking, one studying the conditions of communication. Santaella-Braga (1999: 388-393) has argued that Peirce's

1 Here I am elaborating views I have already defended in Gava (2014: 58-62). 
introduction of the term methodeutic reflected a relevant development and broadening of the scope of the third branch of logic, which resulted in the inclusion of a theory of the methodology of science. This seems to imply that speculative rhetoric should be considered a subclass of methodeutic, which continued to be part of methodeutic after the broadening took place. A different position has been defended by James Liszka, who argued that speculative rhetoric and methodeutic emphasize respectively different elements of the same science, whose job "is not so much the communication of knowledge already developed, but an understanding that the attainment of knowledge is itself involved in a process of inquiry within a community" (2000: 470). Other scholars, like Bergman (2000: 245-246) ${ }^{2}$ and Colapietro (2007, 47-8n36) have argued that methodeutic should be considered a subclass of speculative rhetoric, where the latter is a general science concerned with the use of signs in processes of interpretation and communication, while methodeutic deals with sign use in the context of inquiry and the production of knowledge.

I myself side with this last school of interpreters (cf. Gava 2014: Ch. 2) and this paper should be understood as a contribution in that direction. Still, I disagree with the tendency to read the classification of rhetoric studies in "Ideas" as providing evidence in support of this view. The classification in question contains among its subclasses a "rhetoric of science." This has been taken as a confirmation that methodeutic, understood as a "rhetoric of science," is a subclass of speculative rhetoric, which contains also other branches of study (cf. Colapietro 2007: 47-8n36; Bergman 2000: 246). In what follows, I will argue that reading this classification as a classification of speculative rhetoric produces various misunderstandings concerning both speculative rhetoric and methodeutic.

In Section 2, I will first introduce the classification as it is presented by Peirce in "Ideas" and list some problems that immediately arise when we identify methodeutic with the rhetoric of science. Then, in Section 3, I will elucidate Peirce's distinction between a universal art of rhetoric, speculative rhetoric, and ordinary rhetoric. In Section 4, I will argue that the classification of rhetoric studies in "Ideas" should be seen as a classification of the ways in which we can obtain different ordinary rhetorics specifying the contents of speculative rhetoric for different contexts of sign use. To finish, in Section 5, I will propose a different approach to support the claim that methodeutic is a subclass of speculative rhetoric.

2 More recently, Bergman has defended a more dynamic view on the relationship between methodeutic and rhetoric. He argues that these disciplines should be seen "as complementary approaches or perspectives within the same frame" (2009: 64). This seems to lean toward the perspective introduced by Liszka. 


\section{The classification of rhetoric studies in "Ideas, stray or stolen, about scientific writing”}

According to the classification that Peirce presented in "Ideas," rhetoric studies should be divided in accordance with the following schema:

i. According to the special nature of the ideas to be conveyed;

i.i. rhetoric of fine art;

i.ii. rhetoric of practical persuasion;

i.iii. rhetoric of science;

i.iii.i. rhetoric of communication of discoveries;

i.iii.ii. rhetoric of scientific digests and surveys;

i.iii.iii. rhetoric of application of science to special kinds of purposes;

ii. according to the special class of signs to be interpreted;

ii.i. rhetoric of speech and language;

iii. according to the special nature of signs into which the interpretation is to take place;

iii.i. rhetoric of signs to be translated into human thought. (EP 2: 329, 1904)

If we assume that this classification is one of speculative rhetoric and we then try to locate methodeutic within it, it is almost inevitable to identify methodeutic with the rhetoric of science. However, this identification seems problematic for at least two reasons: (1) methodeutic would not be concerned with the attainment of scientific discoveries, but only with their communication and application, and (2) methodeutic would be limited to a consideration of procedures in the sciences.

Concerning (1), Peirce is clear in stressing that methodeutic should at least also consider principles governing inquiry. For example, in the "Carnegie Application" he writes: "although methodeutic has not the same special concern with them, it has to develop the principles which are to guide us in the invention of proofs, those which are to govern the general course of investigation, and those which determine what problems shall engage our energies" (NEM 4: 62, 1902). Similarly, he also claims that methodeutic "shows how to conduct an inquiry" (NEM 3: 207, 1911). This focus on the principles guiding the attainment of knowledge is totally absent in the rhetoric of science of the classification in "Ideas." The subclasses of the rhetoric of science are: the rhetoric of communication of discoveries, the rhetoric of scientific digests and surveys, and the rhetoric of application of science to special kinds of purposes. This seems to 
imply that the first interest of the rhetoric of science is the communication of knowledge, while the second is its application. Thus, the rhetoric of science in this classification fails to take into consideration a chief aspect of Peirce's methodeutic.

Concerning (2), Peirce does not seem to limit the scope of application of methodeutic only to scientific investigations, even though scientific inquiry is surely its primary and most important field of use. For example, in the Lowell Lectures of 1903, he maintains that methodeutic is "the theory of the advancement of knowledge of all kinds" (EP 2: 256). This suggests that methodeutic is not only concerned with the method of the sciences, but with principles guiding the development of knowledge that are common to science and everyday life (cf. Gava 2014: Ch. 2). Alternatively, the same point can be made by saying that Peirce had a broad understanding of scientific rationality and thought that the "scientific method" was also used outside of proper science. In fact, already in "The Fixation of Belief," he noticed that "[e]verybody uses the scientific method about a great many things" (W 3: 254, 1877). The fact that methodeutic is applicable outside of proper science is not reflected in the rhetoric of science of the above classification. Peirce's reference to the "communication of discoveries," to "scientific digests and surveys," and to "the application of science" indicates that he has in mind the communication and application of findings made in proper science.

I think this is enough to doubt that the "rhetoric of science" in this classification can be identified with methodeutic. However, if this is true, it becomes also doubtful that the whole classification should be considered a classification of speculative rhetoric. In order to correctly understand what the classification of rhetoric studies introduced in "Ideas" really refers to, it is important to first distinguish between three disciplines that are of central importance in the economy of Peirce's text. This is what I intend to do in the next section.

\section{The universal art of rhetoric, speculative rhetoric, and ordinary rhetoric}

As I have just said, Peirce refers to three different disciplines in "Ideas." These are: the universal art of rhetoric, speculative rhetoric, and ordinary rhetoric. We should thus now determine if these different names refer to distinct disciplines and, if this is the case, we need to establish what these disciplines 
exactly are. Only after having accomplished these tasks can we then inquire what the classification in "Ideas" precisely classifies.

That the universal art of rhetoric and speculative rhetoric should be distinguished is quite clear from Peirce's presentation of them. ${ }^{3}$ In fact, in "Ideas," he introduced both disciplines by drawing a distinction between the two, and he claims that even though, on the one hand, it is not certain that the universal art of rhetoric is actually possible, on the other hand, speculative rhetoric is a science that is in a certain way required and that is also already existing. This seems to imply that they should be considered different disciplines.

Let us cut short such objections by acknowledging at once, as an ens in posse, a universal art of rhetoric, which shall be the general secret of rendering signs effective ... Whether there can be such a universal art or not, there ought, at any rate to be (and indeed there is [my emphasis], if students do not wonderfully deceive themselves) a science to which should be referable the fundamental principles of everything like rhetoric, - a speculative rhetoric, the science of the essential conditions under which a sign may determine an interpretant sign of itself and of whatever it signifies, or may, as a sign, bring about a physical result. (EP 2: 326, 1904)

If thus, from this passage, it is clear that Peirce considers the art of rhetoric and speculative rhetoric as two different disciplines, it is still difficult to grasp what exactly their difference amounts to. The universal art of rhetoric must "be the general secret of rendering signs effective," while speculative rhetoric is "the science of the essential conditions under which a sign may determine an interpretant sign of itself and of whatever it signifies, or may, as a sign, bring about a physical result." It seems that both disciplines have to do with the "effectiveness" of signs, that is, with their capacity to give rise to processes of interpretation and other kinds of effects, but one focus on the "secrets" for doing so, while the other on the "conditions." This distinction can be made clearer by introducing Peirce's division between theoretical and practical sciences. In "Ideas," Peirce suggests explicitly that speculative rhetoric is a theoretical science. He says: “'[s]peculative' is merely the Latin form corresponding to the Greek word 'theoretical,' and is here intended to signify that the study is of the purely scientific kind, not a practical science, still less an art” (EP 2: 328, 1904). Theoretical and practical sciences are distinguishable because the former have only the attainment of knowledge as a purpose, while the latter have some additional aim. In Peirce's words: a practical science "embraces whatever scientific inquiry is conducted with a view to some ulterior end" (EP 2: 458, 1911). This

3 Among Peirce scholars, Colapietro tends to identify speculative rhetoric and the universal art of rhetoric (cf. 2007: 30), while Bergman correctly distinguishes between the two (cf. 2000: 245, 2009: 63). 
suggests that speculative rhetoric must identify "conditions" because it aims only at clarifying the general rules and principles that governs the "life" of signs in interpretations and other kinds of effects. By contrast, the universal art of rhetoric focuses on "secretes" because it aims at providing practical "tools" we can use, when we want to obtain particular kinds of effects by means of signs.

Now turning to ordinary rhetoric, it seems that it should be distinguished from both speculative rhetoric and the universal art of rhetoric. It should be distinguished from speculative rhetoric because one of the purposes of "Ideas" is that of clarifying how ordinary rhetoric should be developed in accordance with speculative rhetoric.

Speculative rhetoric has been comparatively neglected; yet enough has been done by two or three analysts to give results comparable in extent and value with the pure scientific contents of an ordinary textbook on logic - enough, therefore, to afford no little guidance in forming opinions about ordinary rhetoric, and to give a notion of what the general character of its influence upon ordinary rhetoric is likely to be. (EP 2: 327, 1904)

But it should be also distinguished from the universal art of rhetoric. Both speculative rhetoric and the universal art of rhetoric are general in character, that is, they identify principles and tools applicable to general categories of signs. ${ }^{4}$ By contrast, we cannot have one single ordinary rhetoric, but we have different ordinary rhetorics that specify rhetorical principles for particular classes of signs. Accordingly, in what is probably an alternative draft of "Ideas," Peirce claims that "[i]f this general study be called universal rhetoric, there will be a special rhetoric for each medium of communication" (MS 777: 6, c.1904). Given that the topic of MS 777 is the same of MS 774, that is, of the manuscript of "Ideas" published in EP, and given that, as we will see, Peirce makes similar contentions in MS 774, it is here plausible to identify universal rhetoric with speculative rhetoric and special rhetoric with ordinary rhetoric. If

4 That the universal art of rhetoric is general in character is evident from the fact that it is called "universal." This is confirmed when Peirce specifies that it is the "general" secret of rendering signs effective,

including under the term "sign" every picture, diagram, natural cry, pointing finger, wink, knot in one's handkerchief, memory, dream, fancy, concept, indication, token, symptom, letter, numeral, word, sentence, chapter, book, library, and in short whatever, be it in the physical universe, be it in the world of thought, that, whether embodying an idea of any kind (and permit us throughout to use this term to cover purposes and feelings), or being connected with some existing object, or referring to future events through a general rule, causes something else, its interpreting sign, to be determined to a corresponding relation to the same idea, existing thing, or law. (EP 2: 326, 1904) 
thus, on the one hand, speculative rhetoric identifies general principles of interpretation, on the other hand, there will be different ordinary rhetorics specifying those general principles for particular contexts of sign use. This is also confirmed in "Ideas" when Peirce claims that we should develop different ordinary rhetorics elucidating particular rhetorical rules that would for example apply only in the context of some subdivision of science, or only for languages belonging to the same family.

The rhetoric of communications of discoveries will vary again according as the discoveries belong to mathematics, to philosophy, or to special science; and further varieties, by no means insignificant, will result from the subdivision of the sciences. One principal kind of rhetoric resulting from the second mode of specialization would be the rhetoric of speech and language; and this mode again would differ for languages of different families. The rhetoric naturally adapted to a Shemitic tongue must be very different from a rhetoric well suited to Aryan speech. Moreover, each Aryan language has, or ought to have, its special rhetoric differing from that of every closely allied languages. (EP 2: 329, 1904)

Making clear this difference between speculative and ordinary rhetoric has for Peirce also the advantage of allowing us to recognize the limited validity of some rhetorical rule: "[o]ne effect of basing rhetoric upon the abstract science would be to take down the pretensions of many of the rhetorical rules and to limit their application to a particular dialect among the dialects of literary English" (EP 2: 329, 1904). Therefore, we can conclude that while speculative rhetoric identifies general rules and principles of interpretation, ordinary rhetorics specify these rules and priciples for different contexts of sign use.

This analysis should have provided enough textual evidence in favor of a differentiation between the universal art of rhetoric, speculative rhetoric, and ordinary rhetoric. It should have also given an idea of what are the different purposes and scopes of application of these disciplines. What we have to do now is to go back to the classification introduced in Section 2 and investigate how it relates to these three disciplines.

\section{What does the classification in "Ideas" classify?}

That the classification of rhetoric studies in "Ideas" is not a classification of the subclasses of the universal art of rhetoric becomes immediately clear if we take into consideration the two sentences that introduce the classification itself. 
Peirce here only mentions ordinary rhetoric, even though it is not immediately evident what its role is in the classification.

\begin{abstract}
The general trend of the modifications that would be introduced into ordinary rhetoric by regarding it as a structure reared upon the foundation of the abstract study aforesaid would be determined in great part by the circumstance that the immediate basis of this ordinary rhetoric would be conceived to be merely one of a large number of special studies, or rather as one group of a large number of groups of special studies. For the specialization would be of three modes: first, according to the special nature of the ideas to be conveyed; secondly, according to the special class of signs to be interpreted ... ; and thirdly, according to the special nature of the class of signs into which the interpretation is to take place. (EP 2: 329, 1904)
\end{abstract}

As I have already mentioned in the previous section, one of the tasks of "Ideas" was to show how we should develop ordinary rhetoric by specifying principles and rules of speculative rhetoric. He seems to touch on the same problem in this passage, so that we could be confident that the "abstract study" to which he refers at the beginning of the first sentence is speculative rhetoric. As a consequence, the classification has to do with the way in which we should specify principles and rules of speculative rhetoric in ordinary rhetoric. But Peirce notices that this task is further complicated by the fact that ordinary rhetoric should take into consideration the specificity of particular contexts of sign use. This is what he means when he says that "the immediate basis of this ordinary rhetoric would be conceived to be merely one of a large number of special studies, or rather as one group of a large number of groups of special studies." In specifying the principles and rules of speculative rhetoric, ordinary rhetoric cannot but be conditioned by the circumstance that it has to find rhetorical principles and rules that are distinctive of determinate contexts of sign use. As I have already suggested, this means that we cannot have a single ordinary rhetoric, but we must have various ordinary rhetorics according to the specific kind of discourse and signs to which they should be applied. Therefore, the classification in question is neither a classification of speculative rhetoric, nor of ordinary rhetoric. It is a classification of the various ways in which we can specify the principles and rules of speculative rhetoric for different contexts of sign use and thus obtain different ordinary rhetorics.

We must conclude that we cannot use the classification of rhetoric studies in "Ideas" for finding out what are the subdivisions of speculative rhetoric. Moreover, as far as this is not a classification of speculative rhetoric, we must not search for methodeutic within it. 


\section{An alternative strategy for distinguishing between speculative rhetoric and methodeutic}

In the introduction, I maintained that this paper should be read as contributing to the reading of Peirce's speculative rhetoric, which maintains that methodeutic is a subdivision of it. This claim could sound now a bit paradoxical, insofar as I have just argued that the classification of rhetoric studies in "Ideas" is actually irrelevant for addressing the relationship between methodeutic and speculative rhetoric, whereas this classification is considered to provide the strongest textual evidence in support of the interpretation just mentioned. Still, I think that attributing to these disciplines interests and objects of study that do not actually belong within them, like in the case of the rhetoric of science for methodeutic, would actually do more harm than good to the line of interpretation here embraced. So, at least in this sense, this paper should be read as contributing to reading methodeutic as a subdivision of speculative rhetoric.

That said, I want to conclude by suggesting a line of inquiry that might provide relevant systematic reasons for considering methodeutic a subclass of speculative rhetoric. It is well known that Peirce uses his three categories as a general principle guiding his various classifications. It is the basic principle of his classification of the sciences and it animates his numerous orderings of signs. For example, in the classification of the sciences, the latter are almost always divided in groups of three. Furthermore, after having recognized the role of a particular science within a group of three sciences according to the categories, we can then further divide the science in question in three subclasses by using the categories again. Thus, for example, logic is a subclass of the normative sciences, which, within its grouping, expresses the category of thirdness. But logic is then further divided into speculative grammar, critic, and speculative rhetoric, to which we can respectively associate the categories of firstness, secondness, and thirdness (cf. EP 2: 258-260, 1903). In the context of his logic, Peirce expresses this thought also by saying that speculative grammar takes into consideration signs in themselves, critic studies the relationship of the sign to the object, while speculative rhetoric considers the relationship of the sign with its interpretant, where arguably here the sign is considered in relationships of growing complexity associable to Peirce's categories.

Obsistent logic, logic in the narrow sense, or Critical Logic, is the theory of the general conditions of the reference of Symbols and other Signs to their professed Objects, that is, it is the theory of the conditions of truth. Originalian logic, or Speculative Grammar, is the doctrine of the general conditions of symbols and other signs having the significant character ... Transuasional logic, which I term Speculative Rhetoric, is substantially what 
goes by the name of methodology, or better, of methodeutic. It is the doctrine of the general conditions of the reference of Symbols and other Signs to the Interpretants which they aim to determine. (CP 2.93, 1902)

Therefore, if Peirce generally uses his categories to find subclasses within his sciences, can we use this strategy to argue that methodeutic is a subdivision of speculative rhetoric? If yes, to which category should methodeutic be associated? Besides, would it not be necessary to find two other subclasses of speculative rhetoric? Here I think it is useful to introduce a division of interpretants made by Peirce, that is, the distinction between emotional, energetic, and logical interpretants. It is not clear to what exactly this classification of interpretants refers, and it is has also been debated if this classification is actually distinguishable from another important division of interpretants, that is, the distinction between immediate, dynamical, and logical interpretants. (cf. Liszka 1996: 25-6, 120-3n12; Short 2007: Ch. 7) I will here side with Thomas Short and read the first division as a division of kinds of interpretants, while considering the second an ordering of modalities of interpretants (Short 2007: Ch. 7). Therefore, on the one hand, emotional interpretants are interpretants where feelings are prominent, while energetic interpretants involve actions in the world and logical interpretants require though and the growth of information through reasoning (cf. CP 5.475). On the other hand, immediate, dynamical, and final interpetants should be identified respectively with potential, actual, and ideal interpretants (cf. Hardwick 1977: 111). Both of these distinctions among interpretants are evidently related to Peirce's categories. However, it seems that a classification of kinds of interpretants fits better our purpose here, that is, that of applying the categories for finding out the role of methodeutic within speculative rhetoric. Accordingly, we must ascertain if we can find subdivisions of speculative rhetoric according to the kinds of interpretants that this subdivision takes into consideration.

I think this is a promising line of investigation for identifying the place of methodeutic within speculative rhetoric. Methodeutic is often associated to the study of the principles animating processes of investigation and knowledge development. Logical interpretation, as a process involving thought and the growth of information through reasoning, plays a central role in this framework. Thus, it seems at least plausible to see methodeutic as what would be the "third" branch of speculative rhetoric, the branch most immediately related to the category of thirdness. There are however two problems related to this strategy. First, Peirce did not identify studies that we could similarly regard as the first and second branches of speculative rhetoric, respectively focused on emotional and energetic interpretation. Still, we could react to this concern by maintaining 
that disciplines of this kind are possible and Peirce did not take them into consideration because he was mainly interested in logical interpretation. Second, it is not clear whether methodeutic is interested in every process of logical interpretation. Peirce's definitions of methodeutic which are most directly associable to a focus on logical interpretation often refer to processes of knowledge development through inquiry: "The third division [of logic], Methodeutic, discusses the relations of signs to their interpretants, that is, their knowledge-producing value" (MS 793: 20, c.1906). However, if we define logical interpretation as a process involving the growth of information through reasoning, it does not seem necessary that this information always results in knowledge. We can for example think of the elaboration of a legal system involving principles and rules as a process of logical interpretation, but arguably this process does not require, or at least not primarily, the development of new knowledge. To answer this concern, we have basically two strategies. Either, we could argue that Peirce should have considered these processes of logical interpretation as being also an object of study for methodeutic. Or, we could stress that methodeutic is a discipline that studies a particular kind of logical interpretation, that is, logical interpretation directed toward the attainment of knowledge, whereas other kinds of logical interpretation should be studied by other subclasses of speculative rhetoric. This second strategy would however render it complicated to find a triadic ordering within speculative rhetoric, insofar as we would have to associate at least two further subclasses to logical interpretation and also to find out two other subclasses respectively corresponding to emotional and energetic interpretation.

Whichever strategy we choose, and in whichever way we decide to identify disciplines focusing on emotional and energetic interpretation, this would mean going beyond what Peirce actually did with the third branch of his logic. Still, I think that the use of the categories and of the distinction between emotional, energetic, and logical interpretants has given us relevant systematic means to understand where to place methodeutic within speculative rhetoric. Methodeutic is first of all concerned with logical interpretation, and thus it would correspond to the subclass of speculative rhetoric most immediately related to the category of thirdness. In Peirce's hands, however, it is limited to the consideration of a specific kind of logical interpretation, that is, logical interpretation directed toward the development of new knowledge. ${ }^{5}$

5 I have used a similar strategy to distinguish between methodeutic and speculative rhetoric in Gava (2014: Ch. 2). 


\section{Conclusion}

This paper should have provided enough evidence to question the assumption that the classification of rhetoric studies in "Ideas" is a classification of the subdivisions of speculative rhetoric. As I have shown, in order to properly read the classification we must first distinguish between three disciplines that Peirce takes into consideration in the paper, that is, the universal art of rhetoric, speculative rhetoric, and ordinary rhetoric. In so doing, it became clear that there is not a unique ordinary rhetoric, but different ordinary rhetorics that specify the principles and rules of speculative rhetoric for particular contexts of sign use. The classification in "Ideas" is exactly a classification of the ways in which we should carry out this specification. This means that the classification in "Ideas" cannot be used to maintain that methodeutic, as the rhetoric of science, is a subdivision of speculative rhetoric. This was the "negative" part of my paper. In the last section, which can be considered the "positive" part of the article, I have tried to propose an alternative way to argue that methodeutic is a subdivision of speculative rhetoric. Methodeutic should thus be understood as that part of speculative rhetoric interested in processes of logical interpretation directed toward the development of knowledge, whereas speculative rhetoric as a whole takes into consideration other kinds of logical interpretation, just as emotional and energetic interpretation.

\section{References}

Bergman, M. 2000. Reflections on the role of the communicative sign in semiotic. Transactions of the Charles S. Peirce Society 36(2). 225-254.

Bergman, M. 2009. Peirce's philosophy of communication. New York: Continuum.

Colapietro, V. 2007. C. S. Peirce's rhetorical turn. Transactions of the Charles S. Peirce Society 43(1). 16-52.

Gava, Gabriele, 2014. Peirce's account of purposefulness: A Kantian perspective. London \& New York: Routledge.

Hardwick, Charles S. (ed.). 1977. Semiotic and significs: The correspondence between Charles S. Peirce and Victoria Lady Welby. Bloomington: Indiana University Press.

Krois, J. M. 1981. Peirce's speculative rhetoric and the problem of natural law. Philosophy and Rhetoric 14(1). 16-30.

Liszka, J. J. 1996. A general introduction to the semiotic of Charles Sanders Peirce. Bloomington: Indiana University Press.

Liszka, J. J. 2000. Peirce's new rhetoric. Transactions of the Charles S. Peirce Society 36(4). 439-476.

Peirce, Charles S. 1931-1966. The collected papers of Charles S. Peirce, 8 vols., C. Hartshorne, P. Weiss \& A. W. Burks (eds.). Cambridge: Harvard University Press. [Reference to Peirce's papers will be designated $\mathrm{CP}$ followed by volume and paragraph number.] 
Peirce, Charles S. 1967. Manuscripts in the Houghton Library of Harvard University, as identified by Richard Robin, Annotated catalogue of the papers of Charles S. Peirce. Amherst: University of Massachusetts Press. [Reference to Peirce's manuscripts will be designated MS.]

Peirce, Charles S. 1976. The new elements of mathematics, 4 vols., C. Eisele (ed.). Berlin \& New York: Mouton de Gruyter; Atlantic Highlands, NJ: Humanities Press. [Reference to Peirce's New Elements will be designated NEM followed by volume and page number.]

Peirce, Charles S. 1982-. Writings of Charles S. Peirce, 7 vols., Peirce Edition Project (eds.). Bloomington: Indiana University Press. [Reference to Peirce's writings will be designated W followed by volume and page number.]

Peirce, Charles S. 1998. Essential Peirce: Selected philosophical writings, vol. 2 (1893-1913), Peirce Edition Project (eds.). Bloomington: Indiana University Press. [Reference to vol. 2 of Essential Peirce will be designated EP 2.]

Santaella-Braga, L. 1999. Methodeutics, the liveliest branch of semiotics. Semiotica 124(3-4). 377-395.

Short, T. L. 2007. Peirce's theory of signs. Cambridge: Cambridge University Press. 